\title{
LEGAL FRAMEWORK IN THE FULFILMENT OF RIGHT TO EDUCATION AS CONSTITUTIONAL RIGHT OF CITIZENS IN BORDER AREA OF NUNUKAN-NORTH KALIMANTAN PROVINCE (Comparison Study and Legal Framework of Right to Education of Citizens in Border Area of Indonesia-Sabah, Malaysia)
}

\author{
Yahya Ahmad Zein', Aditia Syaprillah², Arif Rohman ${ }^{3}$ \\ ${ }^{1}$ Faculty Of Law Borneo Tarakan University \\ JL. Amal Lama No. 1 Tarakan, North Kalimantan, Indonesia \\ Telp./Fax: +62-551-2028655 Email: yahyazein@yahoo.com \\ ${ }^{2}$ Faculty Of Law Borneo Tarakan University \\ JL. Amal Lama No. 1 Tarakan, North Kalimantan, Indonesia \\ Telp./Fax: +62-551-2028655 Email: didit_syaprillah@yahoo.co.id \\ ${ }^{3}$ Faculty Of Law Borneo Tarakan University \\ JL. Amal Lama No. 1 Tarakan, North Kalimantan, Indonesia \\ Telp./Fax: +62-551-2028655 Email: arifrohman_ubt@yahoo.com
}

Submitted: Dec 14, 2017; Reviewed: Dec 20, 2017; Accepted: Dec 29, 2017

\begin{abstract}
The issues was found based on research results in the first year of the model of the fulfillment of the right to education as a constitutional right of citizens in the NunukanNorth Kalimantan Province. The research addresses the policies and models of the fulfillment of the right to education there are still various weaknesses, especially related to the implementation of policies has been contained in the Local Regulations, even worsened by the neglect of border area management principles based on the fulfillment of the right to education that will break the poverty chain, and will strengthen the orientation of border area management based on the welfare of the people. This is of course very interesting when compared to Malaysia's neighboring state Sabah in the fulfillment of the right to education concerning the availability, affordability, acceptance, and conformity of education.
\end{abstract}

The main issues be discussed in this study are how is comparative policies and how os comparison of the framework in the fulfillment of the right to education as a constitutional right of citizens in the border region of Nunukan Indonesia and Sabah Malaysia.

This research is a comparative law study so that it will provide a new policy model of border area management based on the fulfillment of the right to education.

The results of this study conclude that the Malaysian government's policy of opening and developing the port of Tawau at the end of the 19th century and the port of Tawau is the third major destination in Sabah after Kota Kinabalu and Sandakan as evidence that the management of its border areas using the prosperity approach has brought prosperity to Malaysian citizen who is on the border of his country and this is directly proportional to the strengthening of human resources through the Infrastructure and quality of education of his country. The results of the Model comparison indicate that 
there are significant differences in the fulfillment of the right to education as a constitutional right of citizens in the border regions of Nunukan Indonesia and Sabah Malaysia in terms of the conditions of educational infrastructure and access to education information. Affordability of school locations and systems that facilitate the process towards educational facilities. Availability of quality education standards for citizens and the availability of adequate teachers at every level of education.

The aim of this research is not only for the development of science, especially the knowledge of Indonesian border region, but also contributes as a reference for the government related to the policy of border area management in Indonesia, particularly the reference for Local Govenrmment of Nunukan.

Keywords: Citizen in Border Area; Comparison of Legal Framework; Right to Education

\section{PRELIMINARY}

\section{STUDY BACKGROUND}

In line with the authority of border area management in Law no. 23 of 2014 on Regional Governance is specifically regulated in Chapter XVI Part Two of the State Border Area, where the State border area is defined as the outermost Subdistricts directly adjacent to other countries, and related to border management in affirming that the Central Government Authority in the border region includes all authority on the management and utilization of border areas in accordance with the provisions of the laws on the territory of the state.

This research is in line with the authority of border area management in Law no. 23 of 2014 on Regional Governance is specifically regulated in Chapter XVI Part Two of the State Border Area, where the State border area is defined as the outermost Sub-districts directly adjacent to other countries, and related to border management in affirming that the Central Government Authority in the border region includes all authority on the management and utilization of border areas in accordance with the provisions of the laws on the territory of the state.

The authority of the regional government is limited to the delegation of authority given by the Central Government to the Governor as the representative of the Central Government. The limited means an authority solely for coordination of the implementation of border area development based on the guidelines set by the Central Government. Regarding the role of the Regent / Mayor in border management is limited to assist the Governor as the representative of the central government. This is affirmed in Article 361 paragraph (5) which states: "In coordinat- 
ing the implementation of the development of the border area of the Governor as a representative of the Central Government assisted by the regents / mayors". Regents / Mayors in providing assistance in the implementation of the border area development, in principle can assign the district head in the border region. Thus, we can see that the Law no. 23 of 2014 on Regional Government explains, the management and development of border areas so as not to lag behind with the progress of border areas in neighboring countries is the obligation of the Central Government.

Besides that provision, authority of the regional govenrment also covered by the Law No 43 of 2008 on The Territory of The State, particularly in Article 11 stated that the local government, both provincial and district / municipal governments In the management of the State Territory and Border Area have the authority to implement the Government policy and set other policies in the context of autonomy regional and co-administration tasks.

These authority of regional government implemented every regional governments in Indoensia, Based on the results of research in the first year relate to the issue of how is the policy of local government in the framework of fulfilling the right to education of citizens in the border are and how is the legal fremawork in the fulfillment of the right to education as a constitutional right of citizens in the border area of Nunukan Regency, North Kalimantan Province was found that management policy border is the Central Government Authority covering all authority on the management and utilization of border area. The authority of local government is limited to the delegation of authority given by the Central Government to the Governor as the representative of the Central Government in the framework of limited coordination of the implementation of border area development based on the guidelines set by the Government Center. Regarding the role of the Regent / Mayor in border management is limited to assisting the governor as a representative of the central government. In doing so, the policy of the government and local government in the framework of fulfilling the right to education of citizens in the border area. Strictly speaking in the Law on National Education System stated that: The government and local government have the right to direct, guide, assist and supervise the implementation of education. Governments and local governments shall provide services and facilities, as well as ensure the quality of education for every 
citizen without discrimination, and the government and regional governments shall ensure the availability of funds for the implementation of education for every citizen aged seven to fifteen years, Government efforts particularly Nunukan District Government of North Kalimantan Province in order to provide services and facilities, and ensure the implementation of quality education for every citizen without any discrimination has been poured in the regional regulation of Nunukan District number 05 of 2012 on Management and Implementation of Education. The Border Management Model is carried out with a Three Dimensional Comprehensive Approach that is Welfare, Security and Environment, which is done using a welfare-oriented approach that is harmonious with two other securityoriented and environmental-oriented approaches, so that the Legal Model of compliance the right to education as a constitutional right of citizens in the border region of North Kalimantan Province Nunukan Regency should be based on the principle of human rights obligations of Availability (Availability) Education, Accessibility (Affordability) education, Acceptability (education), Adaptability (education) education. The Law of Border Management Model which is oriented to- wards the fulfillment of the right to education, the government must do several things, namely: First, the improvement of education quality. Second, participation and transparency. Third, improving the quality of educators. Quality improvement is done by guaranteeing the certainty of the legal status of teachers in the border area. Fourth, the Allocation of Education Funding is equally and proportionally. In addition, increasing effectiveness and efficiency in the allocation of equitable education funds.

The findings of this study are very important. Accoding to the research conducted in relation to the following issues are: How is the comparation of the policy of fulfilling the right to education of citizens in the border region between Indonesia and Malaysia (Sabah)? And how does the Model compare with the fulfillment of the right to education as a constitutional right of citizens in the border regions of Nunukan Indonesia and Sabah Malaysia?

\section{RESEARCH METHOD}

The type of this research is a comparative law study, so this article compares between Indonesian management and Malaysian government related to the fulfillment of the right to education. The primary legal material is in the form of legislation relating to the issues to be stud- 
ied, while for secondary law materials such as textbooks, research results, scientific journals, magazines / newspapers, paper seminar reports, dissertations and other reading materials relevant to the formulation problem.

\section{RESULT AND DISCUSS}

Comparative Policy on Fulfillment of the Right to Education of Citizens in Border Areas Between Indonesia and Malaysia (Sabah)

\section{Management of Malaysia's State Bor- der Area}

Malaysia is one of the Southeast Asian Countries whose territory is divided into two (2) namely Peninsular Malaysia (Peninsular Malaysia) and in the northern part of Borneo island (Kalimantan). These two areas are separated by the South China Sea and these two separate regions share a geographical form of sloping seafront to dense forests and high hills. The highest peak in Malaysia (and Kalimantan) is Mount Kinabalu which is as high as 4,095.2 meters in the state of Sabah. ${ }^{1}$

The history of Malaysia shows that the location of its strategic Peninsula makes it a busy area of trade traffic. Tan-

\footnotetext{
${ }^{1}$ Khoridatul Anissa, Malaysia Macan Asia (Ekonomi, Politik, Sosial-Budaya \& Dinamika Hubungannya dengan Indonesia, (Yogyakarta, Garasi,2009), page. 24.
}

jungPiai is located in the southern part of Johor state is the southernmost tip of the Asian Continent. Between Sumatra and Peninsular Malaysia is the Malacca Strait which is the most important shipping lane in the world. The capital of Malaysia is Kuala Lumpur, a strategically located city and the most advanced modern city in Malaysia. In addition there is also a city that serves as the administrative capital of Malaysia's federal government of Putrajaya City. Although many of the executive and judiciary branches of the alliance government have moved to Putrajaya (to avoid congestion in Kuala Lumpur), but mud is still regarded as the capital of Malaysia's legislature because that is where the Parliament of Malaysia stands. In addition to Kuala Lumpur's legislative capital is also the center of trade and finance of Malaysia. $^{2}$

Malaysia is one of the 43rd ranked countries in the order of the most populous countries, this is in line with the vast landscape, in terms of the size of Malaysia's 66th place compared to the densely populated countries of the world. The population of Malaysia is about 27 million and the total area exceeds $320,000 \mathrm{~km}^{2}$. The population distribution is certainly based on differences between different

${ }^{2}$ Ibid, Page 25 
regions of Malaysia, as the Federal State of Malaysia is divided into several states and three feredaral territories. The western Malaysia located in the peninsula of Malaysia consists of states: Johor, Kedah, Kelantan, Melaka, Negeri Sembilan, Pahang, Perak, Perlis, Penang or Penang, two communal areas namely (Putra Jaya and Kuala Lumpur), Selangor, and Terenganu. While eastern Malaysia is located
Borneo island (Borneo) consists of three States one territory alliance (Labuan), Sabah, and Sarawak.

The following table shows the distribution of the population in each State and territory of the partnership which is also the basis of the Malaysian government in establishing its border management policy.

Table 1. Distribution of Population In Each State and Territory of the Guild in Malaysia

\begin{tabular}{|c|c|c|c|c|c|c|c|}
\hline States & Population & $\begin{array}{l}\text { Wide } \\
\left(\mathbf{K m}^{2}\right)\end{array}$ & $\begin{array}{c}\text { Population } \\
\text { density }\end{array}$ & $\begin{array}{l}\text { Urban } \\
\text { popula- } \\
\text { tion }\end{array}$ & $\begin{array}{l}\text { Bumi } \\
\text { Putra }\end{array}$ & $\begin{array}{c}\text { Chinese } \\
(\%)\end{array}$ & $\begin{array}{c}\text { India } \\
(\%)\end{array}$ \\
\hline Selangor & 4.188 .876 & 7.960 & 526 & 87,6 & 43,5 & 35,7 & 19,6 \\
\hline Johor & 2.740 .625 & 18.987 & 144 & 65,2 & 57,1 & 35,4 & 6,9 \\
\hline Sabah & 2.603 .485 & 73.619 & 35 & 48,0 & 80,5 & 13,2 & 0,5 \\
\hline Serawak & 2.071 .506 & 124.450 & 17 & 48,1 & 72,9 & 26,7 & 0,2 \\
\hline Perak & 2.051 .236 & 21.005 & 98 & 58,7 & 44,7 & 37,0 & 20 \\
\hline Kedah & 1.649 .756 & 9.425 & 175 & 39,3 & 76,6 & 14,9 & 7,1 \\
\hline KL & 1.379 .310 & 243 & 5676 & 100,0 & 38,6 & 46,5 & 13,4 \\
\hline Penang & 1.313 .449 & 1.031 & 1274 & 80,1 & 27,5 & 61,5 & 10,6 \\
\hline Kelantn & 1.313 .014 & 15.024 & 87 & 34,2 & 95,0 & 3,8 & 0,3 \\
\hline Pahang & 1.288 .376 & 35.965 & 36 & 42,0 & 76,8 & 17,7 & 5,0 \\
\hline $\begin{array}{l}\text { Tereng- } \\
\text { ganu }\end{array}$ & 898.825 & 12.955 & 69 & 48,7 & 96,8 & 2,8 & 0,2 \\
\hline $\begin{array}{l}\text { Negeri } \\
\text { Sembilan }\end{array}$ & 859.924 & 6.644 & 129 & 53,4 & 57,9 & 25,6 & 16,0 \\
\hline Malacca & 635.791 & 1.652 & 385 & 67,2 & 63,8 & 29,1 & 6,5 \\
\hline Perlis & 204.450 & 795 & 257 & 34,3 & 85,5 & 10,3 & 1,3 \\
\hline
\end{tabular}




\begin{tabular}{lccccccc}
\hline Labuan & 76.067 & 92 & 827 & 77,7 & 79,6 & 15,8 & 1,3 \\
& & & & & & & \\
\hline Purtajaya & 45.000 & 148 & 304 & 100,0 & 94,8 & 1,8 & 2,7
\end{tabular}

Source: Department of Statistics Malaysia (National Census of Malaysia Year 2000)

The table above shows that the country that borders directly with Indonesia especially Nunukan Regency of North Borneo is Sabah and Sarawak state, the population of Sabah is 2,603. 485 with an area of 73,619 $\left(\mathrm{Km}^{2}\right)$.the density of Sabah population is 35 with urban population 48.0, where the percentage of the bumiputera is $80.5 \%$, chinese $13.2 \%$ and india $0.5 \%$. The Serawak population $2,071,506$ with an area of 2,071,506 $\left(\mathrm{Km}^{2}\right)$.the percentage of the Bumiputera in Sarawak was $72.9 \%$, while China $26.7 \%$ and India $0.2 \%$.

The border between Malaysia and Indonesia has been measured through a credible official institution, the Chairman of Setiausaha Ministry of Original Resources and Nature Around Malaysia, DatukSuboh bin MohdYassin said that up to 2007 has been done and determined 218.4 $\mathrm{km}$ boundary border in the East Kalimantan-Sabah involving 2,661 border markers (border). "Of these 1,498 borders have been made by planting due to damage and loss," while for the West KalimantanSarawak sector along 112.4 KM has been measured involving 528 border markers where 27 of them have been planted. ${ }^{3}$

The management of border areas in Malaysia, especially in Sabah, is basically inseparable from the existence of the equivalent Community in Sabah, which regulates the management of the equivalent area. Agreement on the adoption of a signed political border to separate clearly and formally the territory between modern countries. Determination of the political border between the nation that separates the territory of Malaysia from the territory of Indonesia has been based on the following conventions and agreements:

1. The Boarding Convention signed in London on 20 June 1891.

2. The imperial convention signed in London on 28 September 1951; and

3. The imminent Convention signed at The Hague on 26 March 1928.

The distance between borders on the island of Borneo between Malaysia (Sabah and Sarawak) and Indonesia (Kali-

\footnotetext{
${ }^{3}$ Siti Noorehan Mohd Zain, Perbatasan Malaysia-Indonesia Di Kalimantan dan Komunikasi Politik (Dalam BukuMengelola Perbatasan Indonesia di Dunia Tanpa Batas), (Yogyakarta, Graha Ilmu,2010), Page 234.
} 
mantan) is 2,020 kilometers. The border distance for Sabah is 371 kilometers and the rest is located in Sarawak. The border management model in Malaysia (Sabah and Serawak) basically keeps in mind the traditional areas of the origin community located along the border, where the community takes a physical position as an institutional community. Some traditional settlements or settlements along the border between Sabah and East Kalimantan, from the village of Long Pasia in the west to the village area on Sebatik Island in the east. $^{4}$

The area of the community in Sabah area bordering on Borneo basically consists of three different areas of character. The three areas are Tawau and Palau Sebatik port areas (Tawau District), in Kampung Palungan and Kampung Bantul (Pensiangan Area / Nabawan) and accommodated Long Pasia (Sipitang Area). Generally, the majority of the population are indigenous Sabah ethnic, mainly consisting of ethnic Hamlet, Kadazan, Murut and Bajau that make up the majority population of most of Sabah, including Tawau, Nabawang and Sipitang areas, and small settlement areas this is inhabited by different ethnic residents. For example, in the Long Pasia study area, almost all residents are ethnic Lundayeh. Residents in Sabah frontier also have a long historical relation with the inhabitants of the region such as Kalimantan, Sulawesi or other islands in Indonesia. Indeed, the ethnic relationships established beyond the international borders of politics are inevitable and an important aspect of understanding the daily life of the equality community in Sabah. Therefore, it is not surprising that his position adjacent to the territory of Indonesia and the life of population has sparked Confrontation (1962-1966) which shows the anger and rebuttal of the Indonesian government of Malaysia carrying the inclusion of Sabah and Sarawak territory into the territory of Malaysia. ${ }^{5}$

One that also greatly influences the border area management model in Malaysia is Malaysia's New Economic Policy (DEB). It is seen that since the implementation of Basic New Economic policy (DEB) in the early 1970s, the progress of the Malaysian state grew rapidly. Among the six ASEAN member states it appears that Malaysia and Thailand have succeeded in trailing Singapore, which in this case

\footnotetext{
${ }^{5}$ Ibid, Page 20
}

\footnotetext{
${ }^{4}$ Kntayya Mariappan\&Zaini Othman, "Sempadan Antara Bangsa Dalam Kehidupan Komuniti Persempadanan", (Jurnal Universiti Malaysia Sabah 2010), Page 17.
} 
has already become one of the advanced industrial countries in Southeast Asia. ${ }^{6}$

According to Fu-chen Lo and Byung-Naik Song (1987: 465), one way to prove that progress is to look at the NGP of each ASEAN country. The research shows that in 1985 the NGP of Indonesia was the lowest among ASEAN countries, ie US \$ 540 compared to US \$ 860 for Malaysia and Thailand; followed by the Philippines approximately US \$ 660. In the period 1965-1975 average growth of NGP Indonesia about $8.1 \%$ compared to $6.8 \%$ for Malaysia. But the period 19731984, Malaysia's economic growth increased very rapidly, ie $7.3 \%$ per year, on the contrary IndonesIA declined to reach $6.8 \% .^{7}$

Malaysia's relatively rapid progress over the past two decades is an indication that the country's development strategy has succeeded in making Malaysia a prosperous country and this also has implications for the well-being of its people in the country's border region. Although the agricultural sector still dominates the country's foreign exchange but since 1971 its

${ }^{6}$ See: $\quad$ M.Arif Nasution, Orang Indonesia di Malaysia (Menjual Kemiskinan membangun Identitas) (Yogyakarta, Pustaka Pelajar, 2001), Page 36.

${ }^{7}$ See: Fu-chen Lo \& Byung-Naik Song, Industrial restructuring of the ESEA (East and Southheast Asian) Economies, (Kuala Lumpur, Asian Pacific Development Centre,1987), Page 465. contribution has gradually decreased from $43.8 \%$ in 1960 to $37.2 \%$ in 1970 , and in 1985 only about $30.4 \%$ only Role and contribution of the agricultural sector to the increasing GNP decline is an inevitable process, especially in order to change Malaysia's economic structure from the dominance of the agricultural sector to the industrial sector's prominence. Similarly, labor in the agriculture sector also declined, from $55.1 \%$ (in 1965) to $35.7 \%$ in 1985. In contrast, the state of the industrial and service sectors was the opposite of what occurred in the agricultural sector where its contribution to Malaysia's GNP increased by $7.6 \%$ in the period 19711975 , and continued to increase to $8.9 \%$ in the era of $1976-1980 .{ }^{8}$

The progress of the industrial sector is one of the goals Malaysia is highly expected to have since the foundation of the New Economy. Encouraging developed countries to invest their capital in this country with facilities is one of the most appropriate straters to achieve that goal. Therefore, it is not an exaggeration if Malaysia has made rapid progress among Southeast Asian countries. According to Fu Chen Lo and ByungNak Song in 1984 countries, Malaysia has reached the 'Middle to Late Stage' in spearheading its in-

\footnotetext{
${ }^{8}$ M.Arif Nasution, op.cit, Page 38.
} 
dustry sector in Southeast Asia. This situation is one level below the progress of South Korea. Until 2000 the Malaysian industrial sector position was estimated to have reached 'Fir Stage' (Fourth Industrial Recycling Stage). On the contrary, the progress of Indonesian industry in 1984 is still relaatif far compared with the achievement of Malaysia, which is still in the early position to the middle (Early to Middle Stage). In 2000 the advancement of Indonesian insudtry was estimated to be at the 'Late Stage' level with China and the Philippines. $^{9}$

The rapid development of the economic sector, especially after the New Economic Foundation has been implemented, also spreads to the development of a border area oriented to sufficient resources, so that the borders of Malaysia are developed by changing the direction of development policies that tend to be oriented towards outward-looking, thus it is used as a gateway to economic activity and trade with neighboring countries. The approach to the development of the state border areas, in addition to use a security approach, also uses a welfare approach, with special attention directed to the development of community communities in match. This is can be seen from the

${ }^{9}$ Fu-chen Lo\& Byung-Naik Song, op.cit, Page 477. placement policies and activities of residents in the port area of Tawau (directly adjacent to Sebatik) which has formed a living community situation of active communities because of the movement of the population and the traffic activity of Malaysian-Indonesian manship so rapidly in this area. The policy of the Malaysian government to open and develop the port of Tawau at the end of the nineteenth century as evidence that the management of its border areas using the prosperity approach has brought prosperity to Malaysian citizens on its borders. Tawau has become the entrance of the inhabitants of the surrounding areas, especially Indonesia and the Philippines besides the people of China, even the dependence of citizens in the border region of Indonesia (Sebatik) to Tawau in fulfiling their daily needs is very high. ${ }^{10}$ In fact, many Indonesian citizens from the region of Nunukan and Sebatik for example has occupied the village area in tawau since the early 1980 s. So today

\footnotetext{
${ }^{10}$ West Sebatik Sub-district, M.Burhanuddin, S.IP.MM. said that the dependence on Tawau (Malaysia) to fulfil the daily needs of the people of Sebatik (Indonesia) has long been going on since even before nunukan expanded into districts, cross-border trade between Sebatik and Tawau is already happening, this is in the resulting distance to Tawau as a region that provides basic needs of society can be traveled easily compared to the region itself to Indonesia. (Interview Radar Tarakan with M.Burhanuddin, S.IP.MM, Sebatik Barat Subdistrict, in Nunukan, 25 Okrober 2013.).
} 
there are various ethnic groups from Indonesia and the Philippines are found in Tawau such as Bugis, Banjar, Tidung, and Suluk. Even the data show that much larger population in the category of "Indonesia" and "other son's land" occupied Tawau region that centered on the area around the port of Tawau port. Tawau is also well known in the present as the main Buginese placement area in Sabah. Kampung Pasir Putih Baru, Kampung Baru Tanjung Tengah, and Kampung Tanjung Batu Laut are the main areas for locating bugis people. It is also found in the area of the village known as the "ice box" is the immigrant population of the Suluk of the Philippines. ${ }^{11}$ Likewise with the movement every day where Indonesian citizens cross the border between countries and into Tawau (sabah region) and the territory of Indonesia based in Sebatik and in Nunukan also a part that encourages the welfare of Malaysian citizens in the border region of the country.

The policy of managing the welfareoriented state borders has caused a very significant difference between Tawau (Sabah-Malaysia) and Sebatik (NunukanIndonesia). In general there are disparities in economic conditions and economic growth and even less balanced public, so-

\footnotetext{
${ }^{11}$ See: Kntayya Mariappan\&Zaini Othman, op.cit. Page 26-27
}

cial and cultural services much different, this is reflected from the conditions: ${ }^{12}$

1. Very lack of economic infrastructure in Indonesia's border region (Sebatik), while Malaysia's border economic infrastructure (Tawau) is much better.

2. The lack of transportation, communication, information, and banking in the border areas of Indonesia (Sebatik), while in the border region of Malaysia (Tawau) is much better.

3. The high poverty rate in the border area of Indonesia (Sebatik), while in the border region of Malaysia (Tawau) is much better.

4. The isolation of people in the border areas of Indonesia (Sebatik), due to the low accessibility of border areas to centers of growth, markets and services, either by land, sea or air. While in the border region of Malaysia (Tawau) is much better.

5. Very lack of Condition of educational facilities, health, and access to information in the border areas of Indonesia (Sebatik), while in the border region of Malaysia (Tawau) is much better.

\footnotetext{
${ }^{12}$ This result is consistent with the observations of the authors who see a very significant difference between Sebatik (Nunukan-Indonesia) and Tawau (Sabah-Malaysia), whereas the distance between Sebatik and Tawau takes only 15-25 minutes using Speddboat.
} 
The high economic and development gap in the border region between Malaysia and Indonesia especially related to the Education will of course have much impact on the life and socio-cultural behavior of the community, thereby resulting in the level of their social life left behind compared to the people in neighboring countries and with communities outside the region state borders.

\section{Education Policy In Malaysia For Citi- zens in areas far from central govern- ment (Out-of-Town)}

Since the Second Plan of Malaysia (1971 to 1975), Malaysia has essentially implemented a basic development towards poverty alleviation and the reduction of socio-economic polarization, especially among people in remote areas from remote (out-of-town) and city (Malaysian, 1971). Based on this principle various businesses are run to continue to educate the community not only formally but also informally for all generations. In this context Education becomes very important as an effort to overcome various problems that exist. The vast efforts of the Malaysian kingdom in order to speed up the living standard of the people can be seen by the establishment of various agencies in the ranking of alliances, regions and countries to implement various development programs for the benefit of the people. And the undeniable truth is that the success of improving people's living standards is the result of efforts made by the Malaysian kingdom through achievements in the fields of education, health, industry and so on. The proof, since two and a half decades since 1970, Malaysia has made remarkable progress in terms of economic growth while fulfilling its social objectives (Malaysia, 1999: 4-5). ${ }^{13}$

In the aspect of education the Malaysian Government has undertaken various policies and programs that are oriented to the development of remote areas (actually including in this case are border areas). For example, it shows that the educational aspect is a very important instrument in order to improve the quality of life in Malaysia. Therefore, in the framework of the First Malaysia Long-Term Plan 1971 - 1990 (RRJP1), access to education has been made one of the main steps that must be done well in order to reduce the deep difference between education in urban and remote areas. Malaysia

\footnotetext{
${ }^{13}$ Quoted from: Di kutipdariSitiMasayuRosliahBintiAbdul Rashid, Peluang Dan Cabaran Pendidikan Dalam Kalangan Masyarakat Luar Bandar : Satu Kajian Kes Isi Rumah Melayu Miskin Di Jajahan Bachok, Kelantan, UniversitiSains Malaysia (tesis) , 2008.(language adapted to the Indonesian language)
} 
has provided substantial budgets to wake the stage of student education in the remote region. This policy is also followed up with the Low School Supplementary Food Program (RMTSR) ${ }^{14}$ and School Dairy Program ${ }^{15}$ with an adequate budget. For RMTSR's implementation time is not more than 190 school days with a budget of RM2.50 for a day student for the territory of Peninsular Malaysia and RM3.00 for a day student residing in the Sabah, Sarawak and Wilayah Persekutuan Labuan areas (beginning in 2015, this is of course in order to improve the learning achievement of children in remote areas. ${ }^{16}$

\footnotetext{
${ }^{14}$ The RMT program will start on the first day of schooling for student from 2 to 6 years. For Year 1 students RMT will be given on the first day of schooling for February of that year.

${ }^{15}$ The School Milk Program is implemented simultaneously with the Food Add Plan. This program is implemented for students rather than poor families who contribute family content at low socioeconomic status to get a balanced diet while in school. The program also aims to improve the school's low school enrollment and attendance to ensure physical growth, general mental health and general well-being of school students. PSS also aims to encourage students to drink milk in the early grades. The student selection criteria are comprised of low school pupils especially from out of town and families with monthly income of RM 400 and less, ie RM800 per capita. PSS is also a program implemented by the Malaysian Ministry of Education along with milk producers in harmony with the Malaysian Pensyarikatan concept. This program, which was launched in 1983, has been extended to all countries starting in 1995 except Sabah with its own milk program.

${ }^{16}$ For example in Kelantan, Kelantan State Department (JPN) received a budget of approximately RM54.6 million over the Central Kingdom during 2007 to be distributed to over
}

In essence Malaysia also taken concrete steps to ensure the advancement of education in remote areas that must go hand in hand with education in urban areas, this is due to a good understanding of the relationship between issues of education decline in remote areas will have an impact which is negative towards development in Malaysia, where the lack of education will make the citizens of the remote areas will be unable to manage the existing sources of development. And this, of course, will be the cause of the increasingly distant social strata between the in remote areas and urban areas. The concrete steps that have been undertaken by the Ministry of Lessons of Malaysia (KPM) is to involve a number of large schools as many as 5077 schools from 7513 low schools and 792 from 2045 secondary schools in Remote areas. Given

170,000 students and poor students across the country. Rather than that amount, RM16.8 million is billed to help 134,000 high school students categorized as poor to attend the collection of Wang AmanahPelajarMiskin (KWAPM) since last January so now. In addition, the allocation is concerned with helping 71,785 poor students of Year 4,5 and 6 to attend additional classes to the baucertuisyen scheme. JPN also lists as many as 38,000 more poor students from across the country who are given two more assistance schemes namely RM7 million RM7 million Extra Low-Cost Food (RMTSR) and School Dairy Program worth RM3.8 million (Utusan Malaysia, 11 Jun 2007). (See SitiMasayuRosliahBinti Abdul Rashid, Opportunities And Education Branch In The Outside of the Community: One Study of Content of Poor Malay Houses in Bachok, Kelantan). 
the importance of this out-of-school education development, KPM has worked with the National Implementation Task Force (NITF) to add high-impact NITF projects to this educational development. An additional of RM2.6 billion has been devoted to activities that can minimize the difference in progress between education in remote and inland areas with urban areas especially in Sabah and Sarawak. The development of this infrastructure will also benefit the 2.2 million students and 14,000 teachers in remote and inland areas. ${ }^{17}$

One of the most interesting Patterns of the Malaysian kingdom in addressing the problem of education for citizens in remote areas is by providing convenience and assistance in education, the Kingdom of Malaysia has taken various steps and efforts to assist the community from poverty through education. For example, in order to ensure the adequacy of the education budget, the Malaysian kingdom has added the budget to around 400,000 poor students across the country by increasing the budget from RM20 to RM50 a month following up the assistance scheme of the Wang Amanah Lesser Student Assistance Group (KWAPM), from 2007 (Malaysia, 2006b: 342). This step is one way to re-

${ }^{17}$ Ibid (Minister of Education of Malaysia, 2007) duce the burden of the family in the aspect of educational budgeting for remote communities / periphery (outside Bandar). ${ }^{18}$

The emphasis on the educational aspect of the Malaysian government is basically due to the realization that education will be able to change the standard of living of a society. These approaches ranging from pre-school level to the highest ranking are the foundation in an effort to accelerate the process of educational progress, especially in terms of providing access and improving the quality of education in Malaysia.

The Framework of fulfillment of right to education for citizens in the Malaysian border region of Sabah.

Country border area is Regency / City region which is geographically and demographically bordered directly with neighboring country and / or high seas. The border area consists of land and sea border areas, which are widely spread with diverse typologies, ranging from inland to small islands of the outer (outer). The Border area as the territory of state sovereignty is in principle very important

\footnotetext{
${ }^{18}$ Di kutip dari Siti Masayu Rosliah Binti Abdul Rashid, Peluang Dan Cabaran Pendidikan Dalam Kalangan Masyarakat Luar Bandar : Satu Kajian Kes Isi Rumah Melayu Miskin Di Jajahan Bachok, Kelantan, Universiti Sains Malaysia (tesis), 2008. (bahasa disesuaikan dengan bahasa Indonesia)
} 
in showing the existence of a country. The sovereignty of language is defined as a supreme authority over state, regional, and other governments. Sovereignty according to MochtarKusumaatmadja is a trait or an essential characteristic of a country, where the state is sovereign (possesses supreme power), but has its limits ie the sphere of this supreme power is limited by the boundaries of the territory of the country, beyond its territory no longer exists has such power.

Building education systems in various countries is basically very important in order to accelerate the progress and development of the country, this is because the School is not only to spread knowledge but also to apply new values and a complete understanding towards development and modernization. With the existence of an efficient and quality education system, the state can give birth to many professionals to help advance the development of a country. In Malaysia Educational Reform is the idea of the Malaysian Ministry of Education to make an important change in all aspects including curriculum supply and development, school administration, school building and others oriented to the improvement and quality of the State's education. ${ }^{19}$

The Development of Education System in Malaysia The years 2001 to 2010 are the days of Basic Country Insights where the Malaysian Ministry of Education has implemented several new elements based on the Education Development document. The Education Act is enforced to supplement the existing structure of the education system. Many important matters that have been implemented by the Malaysian Ministry of Education and between the most significant changes in the history of the development of state education were the setting up of the Malaysian Ministry of Higher Education (KPTM) in 2004 (Othman Alhabshi.2012). Six Strategic Plans of Education Development Master Malaysia 2006-2010 have been introduced, name$1 y:^{20}$

1. Fostering a nation state;

2. Awaken human resource / human resource development model;

3. Enforce the national school;

\footnotetext{
${ }^{19}$ Quoted from Zainuddin Bin Hasan,MohdZaki bin Mohammed SomdanNurAzzabintiAbd Aziz, Perkembangan \& Sistem Roformasi Pendidikan Di Malayasia, Jurnal Pendidikan Nusantara Indonesia (vol.1 No.1;2015), Page 113.

${ }^{20}$ Ibid
} 
4. Close the gap of education outside the city / minimize the difference in education in the suburbs;

5. Improving the dignity of the teaching profession; and

6. Increase the brilliance of educational institutions / enhance institutional excellence.

Based on the 6 things that become the strategic plan, the education system in Malaysia has clear guidance (PelanInduk Pembangunan Pendidikan, PIPP 20062010). This of course will have an impact on efforts to produce superior human resources who are able to use knowledge in a proactive, creative, innovative and have good engineering skills.

If we examine the Malaysian government's policy model in the fulfillment of the right to education in particular with regard to citizens in the border region (Substance) it is very clearly seen in Malaysia's strategic development plan of education on the 4th that: the Malaysian government puts one of its education priorities to minimize the difference the fulfillment of the right to education of citizens in urban areas and citizens who are in the suburbs (out of town).

Besides that, the main focus of Malaysia is higher education, so the design of Higher Educational Transformation 2020 introduced. The Malaysian Ministry of Education produced a high teaching matlamate parallel to developments at the time. Based on the Higher Educational Transformation Design 2020, the Institute of Private Higher Learning (IPTA) is divided into three main categories: the University of Inquiry, the Comprehensive University and the Focused University. Malaysia now has approximately 20 IPTAs that have spawned hundreds of thousands of quality and competitive graduates. These changes are the positive steps that Malaysia has made in realizing the 2020 Insight, which is to make Malaysia a developed country and the Center of Educational Brilliance Serantau by $2020 .^{21}$

The Malaysian Education Development Plan 2013-2025 has been basically reviewed since October 2011, the Malaysian Ministry of Education has conducted a comprehensive review of the Malaysian Education System in order to produce a new Educational Development plan. The Kingdom of Malaysia has made a decision to carry out a review of the education system based on increasing international standard of education, increasing the aspi-

${ }^{21}$ Syed Othman Alhabshi,, et.al (quoted from dariZainuddin Bin Hasan,et.al) , Dasar Dan Pelaksanaan Sistem Pendidikan Kebangsaan, Kongres Pendidikan Melayu di Dewan Merdeka, Pusat Dagangan Dunia Putra (PWTC), Kuala Lumpur, pada 1 - 2 September 2013. 
rations of the state, and the expectations of parents and society on the basis of state education in preparing the younger generation to face the 21 st century. Within 11 months of study the Malaysian Ministry of Education has received inputs from various sources such as research reports conducted by education experts from UNESCO, the World Bank, the OECD, and six Layman Religious Studies Institutions. The 11 principles contained in the Malaysian Education Development 20132025 as follows: $:^{22}$

1. Providing access to international quality education.

2. Ensure that every student is professional in the use of Malay and English.

3. Produce Malaysian people who live value.

4. Transformation of the teacher profession as a chosen profession.

5. Ensure high achieving leaders are placed in each school.

6. Endeavor the position of State Education, Regional Education Officers and schools to provide specific solutions based on the need.

7. Utilizing ICT to improve the quality of learning in Malaysia.

\footnotetext{
${ }^{22}$ Malaysia's Education Development plan; PPPM 2013-2025 (some languages are customized using Bahasa)
}

8. Transformation of education delivery skills and expertise.

9. Cooperate with parents, communities and the private sector widely.

10. Maximize student success.

11. Improving the openness of Public accountability. 
Based on the foundations contained in the Malaysian Education Development Plan 2013-2025 above can be described as follows:

\section{Malaysia Education Development Plan 2013-2025}

\begin{tabular}{|c|c|c|c|c|c|c|}
\hline $\begin{array}{l}\text { Accessing } \\
\text { international } \\
\& \text { profession- } \\
\text { al quality } \\
\text { education in } \\
\text { Malaysian \& } \\
\text { English lan- } \\
\text { guage usage. }\end{array}$ & $\begin{array}{l}\text { Malaysian } \\
\text { people who } \\
\text { value the } \\
\text { transformation } \\
\text { of the teach- } \\
\text { ing profession } \\
\text { as a chosen } \\
\text { profession. }\end{array}$ & $\begin{array}{l}\text { High achiev- } \\
\text { ing leaders } \\
\text { are placed in } \\
\text { every school. }\end{array}$ & $\begin{array}{l}\text { Completed } \\
\text { settlement is } \\
\text { based on } \\
\text { necessity. \& } \\
\text { Utilizing ICT }\end{array}$ & $\begin{array}{l}\text { Transform } \\
\text { the skills and } \\
\text { skill of the } \\
\text { delivery of } \\
\text { education. }\end{array}$ & $\begin{array}{l}\text { Work closely } \\
\text { with parents, } \\
\text { communities } \\
\text { and the pri- } \\
\text { vate sector. }\end{array}$ & $\begin{array}{l}\text { Maximize } \\
\text { student suc- } \\
\text { cess. \& open- } \\
\text { ness of Public } \\
\text { accountability. }\end{array}$ \\
\hline
\end{tabular}

The transformation process of Malaysian education system which will be implemented within 13 years consists of several waves, namely:

1. Wave 1 (2013-2015) focuses on improving the system by providing teacher assistance and focusing on basic proficiency.

2. Wave 2 (2016-2020) speed up system repair.

3. Wave 3 (2021-2025) towards success continues the implementation of a more flexible operation.

This plan basically leads to the formation of students who have six main characteristics in order to face the global competition of knowledge, thinking skills, leadership skills, bilingual skills, ethics and religion, and has a national identity. ${ }^{23}$ The policies of the Malaysian govern-

\footnotetext{
${ }^{23}$ Ibid
}

ment, especially the policy on the fulfillment of the right to education of citizens in the suburbs (outside Bandar) basically illustrate the Model of the fulfillment of the right to education which is also reflected in the development of Malaysian Education Repormation, including:

\section{Purpose of Malaysian Education Sys-}

\section{tem}

At the beginning of the 21st century, some developments and changes occurred in the Malaysian education system due to the advancement of the impacts of globalization, liberalization, and the development of information and communication technologies. The challenge of Malaysia today is to awaken an economy based on knowledge or K-economy in order to face competition with other countries. This requires the Malaysian state to raise highly skilled human resources in various fields 
and competitiveness. Since 2004, the Malaysian education system is managed by two ministries, the Malaysian Ministry of Education (KPM), which is responsible for the administration and administration of the national and secondary education system at the primary and secondary levels of schooling, including preschool education, lower education, secondary education and secondary education ; and Ministry of Higher Education (KPT), which is responsible for tertiary ranking education at the level of Higher Learning Institute (IPTA) and Private Higher Learning Institution (IPTS). In determining the direction of the educational system objectives, KPM has composed educational missions as the focus to be achieved in uplifting the dignity of Malaysia in a globalized world. Malaysia's education mission is: ${ }^{24}$ "To build a world-class quality education system to fully develop individual potential and fulfill Malaysian aspirations". The Malaysian Educational Goals that are in harmony with the Mission, namely:

1. Develop a loyal and united Malaysian nation.

\footnotetext{
${ }^{24}$ Jamil Ahmad danNorliaGoolamally, Pentadbiran dan Pengurusan Sistem Pendidikan Malaysia Ke Arah Pendidikan Berkualiti, library.oum.edu.my/repository/160/1/pentadbira $\mathrm{n}$, accessed on 5 Juli 2017
}

2. Develop the faithful, noble, knowledgeable, skilled and prosperous.

3. Provide human resources for the purposes of the country's progress, and

4. Provide educational opportunities to all Malaysian citizens ${ }^{25}$

In order to achieve these goals, Malaysia's education system is based on the National Education Philosophy (FPK), namely: "Education in Malaysia is an effort that is done towards the development of the potential of individuals as a whole and synergize in creating human balanced and harmonious in terms of intellectual, emotion and body based on trust and obedience to God. This effort is to give birth to the knowledgeable Malaysian people, responsible and efficient in achieving the welfare of themselves and contribute to the harmony and prosperity of society and state.

The philosophy of National Education is the cornerstone of Malaysia in facing the challenges and obstacles of $21 \mathrm{st}$ century competition. Malaysia's educational goals in 2020 become a developed country based on the principle that there is a balance of economic asphek, political, social, spiritual and cultural. Malaysia

\footnotetext{
${ }^{25}$ The policy of providing educational opportunities to all citizens of this course will have an impact on the educational rights of citizens who live in remote areas, including citizens who are in the border region of the country.
} 
wishes to be a united nation with high self-confidence, sticking to religious, moral and ethical values as well as a democratic, fair and thorough life, and mastering a dynamic economy, agile and competitive. Malaysia's efforts to reach developed countries, in the era of globalization is not only oriented to capital, barangan and human, but also about the transnational change of ideas, culture, values and identity. Ideas, culture, values and identity become very important in order to anticipate the negative impacts of the current globalization. The formation of a developed and unified Malaysian State is not only based on a resilient economy but also based on equity in the development of all components of society, both urban and rural communities. ${ }^{26}$

In order to achieve various challenges to become a developed country, Malaysia has introduced its National Mission which emphasizes the priority of Human Resources development in order to achieve high achievement in order to support national development, the National Mission emphasizes on five main terraces:

1. Terrace 1 Increase economy in higher value chain 2 . Terrace 2 Increase the awareness of state's knowledge and inno- vation and foster 'first class' 3. Teras 3 Handles socioeconomic imbalance issues that are continuously nurturing and productive 4 . Terrace 4 Increase the stage and quality of life 5 . Terrace 5 Strengthen institutional capability and implementation.

The five terraces of the National Mission will be greatly influenced by the role of education in celebrating, even two of the five terraces, namely the second terrace and the third terrace, declare the role of education directly.

\section{Laws of Malaysia ACT 550 EDUCA- TION ACT 1996}

Education Direction Malaysia International / World

The efforts made by the Malaysian kingdom in producing the best educational system for all its people are basically done very persistently. There are three main stages done in the development of education system in Malaysia between 1963 and 1975.

\footnotetext{
${ }^{26}$ Ibid
} 
Here's a picture of the development of Malaysian education system 1963 S / D 1975 ie

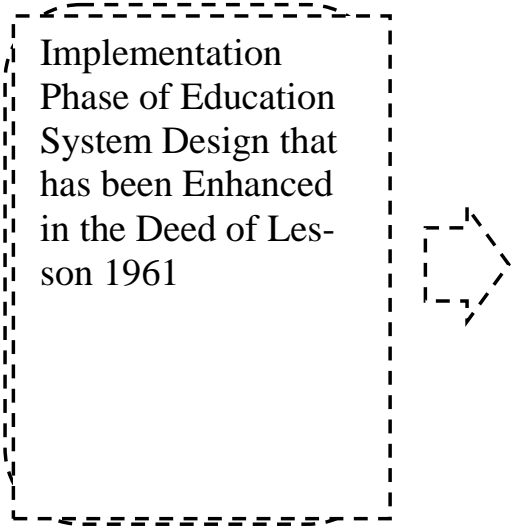

From the figure it can be seen that the development of the Malaysian education system through several steps, namely: The first phase, is the stage of the implementation of educational system design that has been strengthened in the Deed of Lesson 1961. The second stage, is the stage of the implementation of educational design under the Draft of Malaysia with the aim of solving problems economic and social arising at the time. And Third Phase, Adjustment of the system of lessons and exercises to meet the needs of economic development and gave birth to a reliable workforce in implementing the Basic New Economy (DEB).

The development of Malaysian Education International / World Class in principle inspired from by Y.A.B Tun Abdullah Ahmad Badawi, Former Prime of Malaysia at the event KemurPendidikan 2004 he stated "Build World Class
Education System is the agenda of the kingdom of Malaysia". World-class education is an important vehicle for achieving the goal of 2020 insight that makes Malaysians advanced and scientific. The developed society in this context must be able to accept a new, advanced and competitive. The main change agent is education. Education is the most important tool in the development of human resources towards the achievement of state development objectives. World-class education or world class will determine the glory of changing society.

This world-class education is intended for the rapid and dynamic development and progress of education in Malaysia, especially in terms of quality, quantity, and standards recognized and accepted by the international or the world. Viewed from a broad perspective, World Class Education aims to enhance Malay- 
sia's ability and achievement in developing the education sector to spearhead dynamic change and progress: 1. Development of Human Resources; 2. Acceleration of economic growth; 3.Improvement in the level and quality of social policy
4.Moderenisasi and social reform of society 5.The success of cultural thinking and intellect 6.Development of technology and science 7.Successful increase of high literacy rate among the community.

Here's a picture of world-class education in Malaysia for the development and progress of education in Malaysia:

\section{World Class Education}

\begin{tabular}{|c|c|c|c|c|c|c|}
\hline $\begin{array}{l}\text { Human } \\
\text { Reseurce } \\
\text { Development }\end{array}$ & $\begin{array}{l}\text { Economic } \\
\text { Growth } \\
\text { Accelaration }\end{array}$ & $\begin{array}{l}\text { Improvement } \\
\text { of social } \\
\text { policy and } \\
\text { quality level }\end{array}$ & $\begin{array}{l}\text { Modernization } \\
\text { of society }\end{array}$ & $\begin{array}{l}\text { Culture of } \\
\text { thinking and } \\
\text { intellectuality }\end{array}$ & $\begin{array}{l}\text { Technology } \\
\text { and science } \\
\text { development }\end{array}$ & Literacy \\
\hline
\end{tabular}

\section{CONCLUSSION}

1. The policy of the Malaysian government to open and develop the port of Tawau at the end of the nineteenth century as evidence that the management of its border areas using prosperity approach has brought prosperity to Malaysian citizens on its borders. Tawau has become the entrance of the inhabitants of the surrounding areas, especially Indonesia and the Philippines besides the people of China, even the dependence of citizens in the border region of Indonesia (Sebatik) to Tawau in meeting their daily needs is very high. In the policy asylum of the fulfillment of the right to education education, the Government of Malaysia has undertaken var- ious policies and programs that are oriented to the development of remote areas (actually including in this area are border areas). For example, it shows that the educational aspect is a very important instrument in order to improve the quality of life in Malaysia. Therefore, in the framework of the First Malaysia Long-Term Plan 1971 - 1990 (RRJP1), access to education has been made one of the main steps that must be done well in order to reduce the deep difference between education in urban and remote areas. Malaysia has provided substantial budgets to wake the stage of student education in the remote region. 
2. The Malaysian government's policy model in the fulfillment of the right to education, especially with regard to citizens in the border region (Substance), is very clearly seen in one of Malaysia's strategic focus of education development plan: the Malaysian government puts one of its education priorities to minimize the difference in fulfillment of rights for education of citizens in urban areas and citizens who are in the suburbs (out of town). The model for the fulfillment of the right to education is also reflected in: The Purpose of the Malaysian Education System, the Malaysian Education Law (ACT 550 EDUCATION ACT 1996), and the International / World Malaysia's Education Policy Direction.

\section{BIBLIOGRAPHY}

Awang Farouk Ishak, 2009. Strategi Pembangunan Kawasan Perbatasan Kalimantan Timur, Samarinda: Pemerintah Provinsi Kalimantan Timur.

Chung-Tong Wu, Cross-Border Development in a Changing World: Redefining Regional Development Policies. In Edgingtong, David W. et.al. (eds), 2001. New Regional Devel- opment Paradigms, London: Greenwood Press, Vol. 2: 28 - 33

Fu-chen Lo\&Byung-Naik Song, Industrial restructuring of the ESEA (East and Southheast Asian) Economies, (Kuala Lumpur, Asian Pacific Development Centre,1987).

Jamil Ahmad dan Norlia Goolamally, Pentadbiran dan Pengurusan Sistem Pendidikan Malaysia Ke Arah Pendidikan Berkualiti, library.oum.edu.my/repository/160/

1/pentadbiran ,akses 5 Juli 2017

Kntayya Mariappan \& Zaini Othman, "Sempadan Antara Bangsa Dalam Kehidupan Komuniti Persempadanan", (Jurnal Universiti Malaysia Sabah ,2010)

Katarina Tomasevski, 2005. Pendidikan Berbasis Hak Asasi, UNESCO.

Laporan Penelitian, 2009. Kewenangan Pemerintah daerah Dalam Pengelolaan Kawasan Perbatasan di Era Otonomi Daerah (Study Kasus di Kalimantan Barat), Pontianak: Dewan Perwakilan Daerah Republik Indonesia berkerjasama dengan Universitas Tanjung Pura.

M.Arif Nasution, Orang Indonesia di Malaysia (Menjual Kemiskinan membangun Identitas) (Yogyakarta, Pustaka Pelajar,2001). 
Mahendra Putra Kurnia, et.al, 2011 "Keadilan Di Tanah-Tanah Perbatasan", Jurnal Transisi Intrans Institute, Vol. VII, Edisi No. 7, tanpa halaman.

Maruarar Siahaan, 2011, "Hak Konstitusional dalam UUD NRI 1945”, Salatiga, 3 Desember

MiminRukmini\& R Muhammad Mihradi, 2006.PeganganRingkasPemenuhan

HAM PendidikandanKesehatan di Daerah, Jakarta: Pusat Telaah dan Informasi Regional \&European Initiative Democracy and Human Rights (EIDHR) Uni Eropa.

Mochtar Kusumaatmadja, 1982. Pengantar Hukum Internasional, Buku-I-Bagian Umum, Bandung: Bina Cipta.

Siti Masayu Rosliah Binti Abdul Rashid, Peluang Dan Cabaran Pendidikan Dalam Kalangan Masyarakat Luar Bandar : Satu Kajian Kes Isi Rumah Melayu Miskin Di Jajahan Bachok, Kelantan, Universiti Sains Malaysia. Syed Othman Alhabshi,, et.al (dikutip dari Zainuddin Bin Hasan,et.al), Dasar Dan Pelaksanaan Sistem Pendidikan Kebangsaan, Kongres Pendidikan Melayu di Dewan Merdeka, Pusat Dagangan Dunia Putra (PWTC),
Kuala Lumpur, pada $1-2$ September 2013.

Satjipto Rahardjo, 2000. Ilmu Hukum, Bandung: Citra Aditya.

Kntayya Mariappan \& Zaini Othman, "Sempadan Antara Bangsa Dalam Kehidupan Komuniti Persempadanan", (Jurnal Universiti Malaysia Sabah ,2010.

Katarina Tomasevski, 2005. Pendidikan Berbasis Hak Asasi:

Penyederhanaan Persyaratan Hak Asasi Manusia Global, M Hamka (Penyunting Bahasa Indonesia), Jakarta, Proyek Kerja Sama antara Pelapor Khusus PBB tentang Hak Atas Pendidikan dan Biro Pendidikan Wilayah Asia pasifik UNESCO.

Kementerian Perencanaan Pembangunan Nasional/BAPPENAS, 2010. RPJNM 2010-2014, Jakarta: Direktorat Kawasan Khusus dan Daerah Tertinggal.

Yesmil Anwar \& Sadang, 2008. Pengantar Sosiologi Hukum, Jakarta: Raja Grafindo.

Wahyuni Kartika Sari, 2010. Mengurai Pengelolaan Perbatasan di WilayahWilayah Perbatasan Indonesia (Dalam buku Mengelola Perbatasan 
Indoenesia di Dunia Tanpa Batas), Yogyakarta:Graha Ilmu.

Zainuddin Bin Hasan,Mohd Zaki bin Mohammed Som dan Nur Azza binti
Abd Aziz, Perkembangan \& Sistem

Roformasi Pendidikan Di Malayasia, Jurnal Pendidikan Nusantara Indonesia (vol.1 No.1; 2015). 